\title{
Nutritional status among peritoneal dialysis patients after oral supplement with ONCE dialyze formula
}

This article was published in the following Dove Press journal: International Journal of Nephrology and Renovascular Disease 13 June 2017

Number of times this article has been viewed

\author{
Bancha Satirapoj' \\ Pokkrong Limwannata ${ }^{2}$ \\ Chadarat Kleebchaiyaphum ${ }^{2}$ \\ Janjira Prapakorn ${ }^{3}$ \\ Ussanee Yatinan ${ }^{3}$ \\ Samitti Chotsriluecha ${ }^{3}$ \\ Ouppatham Supasyndh' \\ 'Division of Nephrology, Department \\ of Medicine, Phramongkutklao \\ Hospital and College of Medicine, \\ Bangkok, 'Division of Medicine, \\ Chaiyaphum Hospital, Chaiyaphum, \\ ${ }^{3}$ Division of Clinical Nutrition, \\ Department of Medicine, \\ Phramongkutklao Hospital and \\ College of Medicine, Bangkok, \\ Thailand
}

Correspondence: Bancha Satirapoj Division of Nephrology, Department of Medicine, Phramongkutklao Hospital and College of Medicine, 315 Ratchawithi Road, Ratchathewi, Bangkok 10400, Thailand

Tel/Fax +66 26444676

Email satirapoj@yahoo.com
Background: Malnutrition is an important problem in patients treated with long-term dialysis, and most dialysis patients have lower dietary energy and protein intake. This study was undertaken to examine whether orally administered Otsuka Nutrition Pharmaceutical (ONCE) dialyze formula (ODF) supplement would improve energy intake without mineral and electrolyte disturbances in patients with continuous ambulatory peritoneal dialysis (CAPD).

Methods: The effects of ODF supplementation on nutrition markers including serum albumin and prealbumin concentrations and inflammatory stress in patients with chronic CAPD were evaluated. All patients received daily oral ODF supplements for 15 days. During follow-up, all patients were evaluated clinically and biochemically, and nutritional status was assessed.

Results: Thirty patients with mean age $61.9 \pm 12.3$ years and weekly $K t / V 2.2 \pm 0.4$ were studied. The mean values for nutritional parameters included a body weight of $53.7 \pm 9.5 \mathrm{~kg}$, a serum albumin level of $3.3 \pm 0.4 \mathrm{~g} / \mathrm{dL}$, a serum prealbumin level of $33.8 \pm 11.1 \mathrm{mg} / \mathrm{dL}$, a dietary energy intake of $21.9 \pm 7.1 \mathrm{kcal} / \mathrm{kg} / \mathrm{day}$, and a dietary protein intake of $0.9 \pm 0.3 \mathrm{~g} / \mathrm{kg} /$ day. After 15 -day ODF treatment, these patients had significant dietary energy and protein, carbohydrate, fat, fiber, potassium, calcium, and magnesium intake from baseline $(P<0.05)$. Furthermore, significant improvements were found in nutritional markers including body weight, blood urea nitrogen, and prealbumin levels, but no changes were observed in serum albumin and high-sensitivity C-reactive protein levels. At the end of follow-up, the frequency of patients with moderate malnutrition decreased from $24.2 \%$ to $18.2 \%$, and no increased incidence was observed of hyperkalemia, hyperphosphatemia, and metabolic acidosis.

Conclusion: ODF supplementation ameliorates low dietary energy and nutrient intake as well as improves serum prealbumin and body weight in patients with long-term CAPD.

Keywords: malnutrition, peritoneal dialysis, prealbumin, low dietary energy

\section{Background}

Patients with end-stage renal diseases (ESRDs) that require long-term dialysis are a public health concern worldwide. Common adverse consequences of long-term dialysis include hypoalbuminemia and worsened nutritional status related to increased morbidity and mortality rates. ${ }^{1}$ Malnutrition is common among peritoneal dialysis patients and occurs in 30\%-50\% of patients. ${ }^{2-4}$ Long-term dialysis patients including continuous ambulatory peritoneal dialysis (CAPD) exhibit protein and energy intake levels below National Kidney Foundation Kidney Dialysis Outcome Quality Improvement (NKF-K/DOQI) Guidelines. ${ }^{5-8}$ Several factors contribute to lower dietary intake among dialysis patients, such as anorexia, inadequate dialysis, volume overload, gastrointestinal disease, and comorbid illness. ${ }^{9}$ In addition, among patients with CAPD, 
loss of proteins and amino acids to the dialysate may also play important roles of malnutrition. Administration of oral nutritional supplements would have beneficial effects on the nutritional status among these patients.

The implementation of dietary interventions can be challenging to the medical care team and patients with CAPD. Supplementary protein nutrients induce a significant improvement in caloric intake, serum albumin concentration, muscle strength, and quality of life among dialysis patients. ${ }^{10-12}$ Therefore, oral-specific renal dialyze nutritional supplementation designed to increase energy, protein, and fiber intake and decrease sodium, potassium, and phosphorus might be one therapeutic intervention to improve CAPD outcomes. Currently, no consensus exists on the guidelines concerning the type, time of initiation, or duration of oral nutrition supplements. ${ }^{13}$ In this study, the effects of dietary renalspecific formula or Otsuka Nutrition Pharmaceutical (ONCE) dialyze formula (ODF) supplementation on the nutritional status among patients with CAPD with inadequate calories and protein intake plus hypoalbuminemia were examined. The expected outcome of the primary study was change in the average serum prealbumin and albumin measurements between baseline and follow-up among CAPD patients.

\section{Methods}

Between January and December 2016, stable patients with CAPD for at least 3 months, serum albumin level $<3.8 \mathrm{~g} / \mathrm{dL}$, dietary protein intake $<1 \mathrm{~g} / \mathrm{kg} /$ day, and dietary energy intake between 20 and $25 \mathrm{kcal} / \mathrm{kg} /$ day from the hospital-based dialysis unit were enrolled. Subjects with inadequate dialysis, active congestive heart failure, advanced liver disease, active malignancy, pregnancy, recent episode of peritonitis, or hospitalization within 3 months and active inflammatory condition such as lupus, celiac disease, Crohn's disease, rheumatoid arthritis, and chronic infection were excluded. All subjects signed an informed consent statement before inclusion in the study. The study protocol was approved by the Ethics in Human Research Committee of the Royal Thai Army Medical Department and Chaiyaphum Hospital, Thailand.

All patients had their medical history reviewed. The assessment consisted of anthropometric measurements, dietary intake, and biochemical test. Anthropometric measurements such as body weight, height, and body mass index (BMI) were measured using standard protocols before and after treatment. Casual systolic blood pressure (SBP) and diastolic blood pressure (DBP) were measured using a standard mercury sphygmomanometer applied on the same arm after a 10-minute rest in the sitting position. All patients were subjected to an initial nutritional evaluation; individuals were evaluated for any degree of malnutrition, as measured by the modified subjective global assessment (SGA). Modified SGA evaluated weight loss, dietary intake, gastrointestinal symptoms, functional impairment, presence of edema, muscle wasting, and body fat loss. Levels of SGA were classified as $\mathrm{A}=$ normal to mild malnutrition, $\mathrm{B}=$ moderate malnutrition, and $\mathrm{C}=$ severe malnutrition.

\section{Dietary intake}

A 3-day dietary history of nutrient intake, absolute and adjusted for actual body weight, was obtained before and after the study period. Nutrient composition of the diets was analyzed using the Inmucal National Food Database Program. All participants received oral ODF supplementation added to the regular diet for 15 days. The intervention consisted of oral liquid ODF supplementation at $370 \mathrm{kcal}$ per $80 \mathrm{~g}$ and the following ingredients: $16.98 \mathrm{~g}$ of proteins, $41.19 \mathrm{~g}$ of carbohydrate with soluble dietary fiber (fibersol) $2.25 \mathrm{~g}$, $16.45 \mathrm{~g}$ of fat, $149.9 \mathrm{mg}$ of calcium, $149.9 \mathrm{mg}$ of phosphorus, $206.2 \mathrm{mg}$ of potassium, and $154.4 \mathrm{mg}$ of sodium. Table 1 summarizes all the components in ODF and other commercial dietary supplements.

\section{Biochemical analysis}

Blood samples were drawn in the morning from participants after an overnight fast of 12 hours at baseline and after 15 days of treatment. Plasma concentrations of glucose, hemoglobin, creatinine, blood urea nitrogen (BUN), calcium, phosphorus, magnesium, albumin, and prealbumin were measured. Urea clearance was calculated as $K t / V$, where $K$ is a constant, $t$ is time, and $V$ is total body water. All subjects performed self-directed 24-hour urine collections and underwent residual creatinine and urea clearance. Serum and urine creatinine samples were analyzed using the enzymatic method.

\section{Safety monitoring}

Adverse events that were or were not considered to be related to ODF treatment were monitored. The patients were questioned each time in a systematic way regarding their experiences concerning adverse events during the 15 days.

\section{Statistical analysis}

Each value was expressed as the percentage, mean $\pm \mathrm{SD}$, or median (inter-quartile range), depending on the normality of data distribution. Continuous variables between baseline and 
Table I Comparison of ONCE dialyze formula and other commercial dietary supplements in I,000 kcal

\begin{tabular}{|c|c|c|c|}
\hline Component & ONCE dialyze & Nepro & Ensure \\
\hline \multicolumn{4}{|c|}{$\begin{array}{l}\text { Caloric distribution of } \\
\text { macronutrients (\%) }\end{array}$} \\
\hline Protein & $18 \%$ & $18 \%$ & $16 \%$ \\
\hline Carbohydrate & $42 \%$ & $35 \%$ & $55 \%$ \\
\hline Fat & $40 \%$ & $47 \%$ & $29 \%$ \\
\hline \multicolumn{4}{|l|}{ Source } \\
\hline \multirow[t]{4}{*}{ Protein } & $45.89 \mathrm{~g}$ & $44.94 \mathrm{~g}$ & $20.24 \mathrm{~g}$ \\
\hline & Whey protein isolate & Casein $32.65 \mathrm{~g}(72.66 \%)$ & Casein $14.19 \mathrm{~g}(70.11 \%)$ \\
\hline & $13.5 \mid \operatorname{g~}(29.45 \%)$ & Milk protein $12.29 \mathrm{~g}(27.34 \%)$ & Soy protein $4.19 \mathrm{~g}(20.69 \%)$ \\
\hline & Casein $32.38 \mathrm{~g}(70.55 \%)$ & & Milk protein 1.86 g $(9.20 \%)$ \\
\hline \multirow[t]{6}{*}{ Carbohydrate } & $111.32 \mathrm{~g}$ & $89.18 \mathrm{~g}$ & $72.7 \mathrm{Ig}$ \\
\hline & Maltodextrin $37.03 \mathrm{~g}(33.26 \%)$ & Cornmaltodextrin & Corn syrup solid $28.97 \mathrm{~g}$ \\
\hline & Isomaltulose $60.78 \mathrm{~g}(54.6 \%)$ & $57.09 \mathrm{~g}(64.02 \%)$ & $(39.84 \%)$ \\
\hline & Fibersol $6.08 \mathrm{~g}(5.46 \%)$ & Sucrose $14.14 \mathrm{~g}(15.86 \%)$ & Maltodextrin $24.82 \mathrm{~g}(34.13 \%)$ \\
\hline & FOS $7.44 \mathrm{~g}(6.68 \%)$ & Fibersol II.II g (I2.46\%) & Sucrose $13.50 \mathrm{~g}(18.57 \%)$ \\
\hline & & FOS $6.82 \mathrm{~g}(7.65 \%)$ & FOS, Inulin 5.42 g (7.46\%) \\
\hline \multirow[t]{5}{*}{ Fat } & $44.46 \mathrm{~g}$ & $53.4 \mathrm{lg}$ & $17.65 \mathrm{~g}$ \\
\hline & Canola oil I0.8I g (24.32\%) & HOSO $37.3 \mathrm{l}$ g (69.86\%) & HOSO 10.94 g (61.97\%) \\
\hline & HOSO $5.4 \mathrm{I} \mathrm{g}(12.16 \%)$ & Canola oil $16.10 \mathrm{~g}(30.14 \%)$ & Soybean oil $4.97 \mathrm{~g}(28.17 \%)$ \\
\hline & MCT oil $14.19 \mathrm{~g}(31.91 \%)$ & & Canola oil 1.74 g $(9.86 \%)$ \\
\hline & Rice bran oil I4.05 g (3।.61\%) & & \\
\hline \multicolumn{4}{|c|}{ Micronutrient } \\
\hline \multicolumn{4}{|c|}{ Vitamins and minerals } \\
\hline Vitamin A (IU) & 190.2 & $\mathrm{I}, 764.7$ & $3,508.7$ \\
\hline Vitamin D (IU) & 8.6 & 47.1 & 443.5 \\
\hline Vitamin C (mg) & 101.3 & 58.8 & 126.5 \\
\hline Calcium, mg & 405.1 & 588.2 & $1,052.2$ \\
\hline Phosphorus, mg & 405.1 & 400 & 630.4 \\
\hline Magnesium, mg & 110.3 & 117.6 & 187.0 \\
\hline Potassium, mg & 557.3 & 588.2 & I,567.4 \\
\hline Sodium, mg & 417.3 & 588.2 & 842.2 \\
\hline Carnitine, mg & 281.3 & 148.2 & - \\
\hline Others & As Thai RDI recommend & & \\
\hline
\end{tabular}

Abbreviations: FOS, fructooligosaccharide; HOSO, high oleic safflower oil; MCT, medium-chain triglyceride; ONCE, Otsuka Nutrition Pharmaceutical; RDI, reference daily intake.

at the end of study were compared using paired $t$-tests and Wilcoxon signed ranks test. Chi-square test or McNemar's test was used to examine the categorical variables. A twotailed $P$-value $<0.05$ was considered statistically significant. Statistical analysis was performed by using SPSS for Windows, version 16.0 (SPSS, Chicago, IL, USA).

\section{Results}

A total of 30 hypoalbuminemic patients with CAPD were recruited from the outpatient unit. The patients were all Thais, $39.4 \%$ male with a mean age of $61.9 \pm 12.3$ years. Body weight was $53.7 \pm 9.5 \mathrm{~kg}$ and mean weekly $K t / V$ was $2.2 \pm 0.4$. Mean serum albumin level and prealbumin were $3.3 \pm 0.4 \mathrm{~g} / \mathrm{dL}$ and $33.8 \pm 11.1 \mathrm{mg} / \mathrm{dL}$, respectively. The comorbid diseases among the patients included diabetes mellitus (40\%), hypertension $(25 \%)$, ischemic heart disease $(10 \%)$, and dyslipidemia $(70 \%)$. Clinical characteristics of the patients are shown in Table 2.
Table 2 Characteristics of the study population

\begin{tabular}{ll}
\hline Parameters & $\mathbf{N}=\mathbf{3 3}$ \\
\hline Male $(\mathrm{N}, \%)$ & $13(39.4)$ \\
Age (years) & $61.9 \pm 12.3$ \\
Height $(\mathrm{cm})$ & $158.8 \pm 8.6$ \\
Body weight $(\mathrm{kg})$ & $53.7 \pm 9.5$ \\
Body mass index $\left(\mathrm{kg} / \mathrm{cm}^{2}\right)$ & $2 \mathrm{I} .3 \pm 2.8$ \\
Systolic blood pressure $(\mathrm{mmHg})$ & $141.3 \pm 26.6$ \\
Diastolic blood pressure $(\mathrm{mmHg})$ & $77.7 \pm 15.1$ \\
Hemoglobin $(\mathrm{g} / \mathrm{dL})$ & $10.6 \pm 2.1$ \\
Prealbumin $(\mathrm{mg} / \mathrm{dL})$ & $33.8 \pm \mathrm{II} .1$ \\
Albumin $(\mathrm{g} / \mathrm{dL})$ & $3.3 \pm 0.4$ \\
Fasting plasma glucose $(\mathrm{mg} / \mathrm{dL})$ & $120.9 \pm 52.5$ \\
BUN $(\mathrm{mg} / \mathrm{dL})$ & $45.8 \pm 13.9$ \\
Serum creatinine $(\mathrm{mg} / \mathrm{dL})$ & $8.5 \pm 3.2$ \\
Weekly Kt/V & $2.2 \pm 0.4$ \\
Residual renal creatinine clearance $\left(\mathrm{mL} / \mathrm{min} / \mathrm{I} .73 \mathrm{~m}^{2}\right)$ & \\
High-sensitivity CRP $(\mathrm{mg} / \mathrm{dL})$ & $5.2 \pm 9.8$ \\
\hline
\end{tabular}

Note: Data are presented as $n(\%)$ and mean \pm SD.

Abbreviations: BUN, blood urea nitrogen; CRP, C-reactive protein; $K$, a constant; $t$, time; $V$, total body water; SD, standard deviation. 
Table 3 Dietary intake with 3-day food record at baseline and end of 15-day follow-up

\begin{tabular}{|c|c|c|c|c|}
\hline Per day & Baseline & I5 days & Mean change $(95 \% \mathrm{Cl})$ & $P$-value \\
\hline Energy (kcal) & $\mathrm{I}, 134.4 \pm 280.2$ & $I, 436.1 \pm 264.9$ & 301.6 (223.4 to 379.9$)$ & $<0.001$ \\
\hline Energy (kcal/kg/day) & $21.9 \pm 7.1$ & $27.1 \pm 6.7$ & $5.2(3.8$ to 6.6$)$ & $<0.001$ \\
\hline Protein $(g)$ & $48.0 \pm 16.0$ & $59.9 \pm 11.1$ & $11.9(6.9$ to 16.8$)$ & $<0.001$ \\
\hline Protein (g/kg/day) & $0.9 \pm 0.3$ & $1 . I \pm 0.3$ & $0.21(0.1$ to 0.3$)$ & $<0.001$ \\
\hline Carbohydrate (g) & $155.4 \pm 44.9$ & $186.0 \pm 52.3$ & $30.6(15.7$ to 45.6$)$ & $<0.001$ \\
\hline Fat $(\mathrm{g})$ & $35.5 \pm 12.6$ & $53.1 \pm 13.3$ & 17.6 (13.7 to 21.5$)$ & $<0.001$ \\
\hline Fiber (g) & $5.8 \pm 2.9$ & $11.4 \pm 6.6$ & $5.6(3.2,8.0)$ & $<0.001$ \\
\hline Sodium (mg) & I,957.4 \pm 687.7 & $1,944.2 \pm 800.9$ & $-13.2(-251.4$ to 225$)$ & 0.911 \\
\hline Potassium (mg) & $1,020.3 \pm 379.2$ & 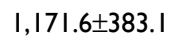 & 151.4 (15.7 to 287.0$)$ & 0.030 \\
\hline Calcium (mg) & $275.4 \pm 161.7$ & $398.4 \pm \mid 46.1$ & $123.0(75.6$ to 170.4$)$ & $<0.001$ \\
\hline Phosphorus (mg) & $506.8 \pm 203.1$ & $559.9 \pm 117.2$ & $53.1(-11.2$ to $I 17.5)$ & 0.102 \\
\hline Magnesium (mg) & $20.7 \pm 19.0$ & $59.0 \pm 17.2$ & 38.3 (32.0 to 44.5$)$ & $<0.001$ \\
\hline
\end{tabular}

Notes: Data are presented as mean \pm SD and mean change $(95 \% \mathrm{Cl})$. $P$-value corresponds to paired $t$-test.

Abbreviations: $\mathrm{SD}$, standard deviation; $\mathrm{Cl}$, confidence interval.

\section{Dietary intake}

Estimated energy and nutrient intake are summarized in Table 3. A significant increase in energy intake from $1,134.4 \pm 280.2$ to $1,436.1 \pm 264.9 \mathrm{kcal} /$ day and protein intake from $48.0 \pm 16.0$ to $59.9 \pm 11.1 \mathrm{~g} /$ day were noted during the study $(P<0.001)$. At the end of the study, dietary intake of carbohydrate, fat, and fiber increased significantly by 30.6 (15.7-45.6) g/day $(P<0.001), 17.6(13.7-21.5) \mathrm{g} /$ day $(P<0.001)$ and $5.61(3.21-8.02) \mathrm{g} /$ day $(P<0.001)$, respectively. In addition, potassium, calcium, and magnesium intake also increased significantly after 15 days of intervention. However, no significant change in sodium or phosphorus intake was found as shown in Table 3.

\section{Nutritional, biochemical, and inflammatory parameters}

Modified SGA scores were used to more clearly identify the effects of ODF on the nutritional status. At baseline, 75.8\% of patients were well nourished and $24.2 \%$ had mild-tomoderate malnutrition. At the end of follow-up, the frequency of patients with mild-to-moderate malnutrition decreased by $6 \%$ in the study group ( 24.2 vs $18.2 \%, P=0.625)$.

Changes in nutritional indices are shown in Table 4. Overall, body weight and BUN significantly increased during the study. At the end of study, patients had higher prealbumin concentrations compared with the baseline values (33.8 \pm 11.1 vs $35.4 \pm 10.1 \mathrm{mg} / \mathrm{dL}, P=0.004$, Figure 1$)$. However, compared with the baseline values, patients had non-significantly higher values of albumin, fasting plasma glucose, white blood cell count, hemoglobin, and high-sensitivity C-reactive protein (CRP) after 15-day supplementation.

At the end of the study, serum bicarbonate and chloride decreased significantly by $-1.61(-2.42$ to -0.79$) \mathrm{mEq} / \mathrm{L}$ $(P=0.002)$ and $-4.35(-5.99$ to -2.7$) \mathrm{mEq} / \mathrm{L}(P<0.001)$, respectively. In contrast, serum sodium and calcium increased significantly by 1.89 ( 0.76 to 3.03$) \mathrm{mEq} / \mathrm{L}(P=0.002)$ and 0.16 ( 0 to 0.32$) \mathrm{mEq} / \mathrm{L}(P=0.046)$, respectively. However, dietary intervention did not significantly change the levels of serum creatinine, potassium, phosphorus, urine sodium, residual renal urea clearance, and creatinine clearance, but it improved the incidence of hypokalemia ( $78.8 \%$ vs $27.3 \%, P=0.001$ ).

\section{Safety profile}

The rate of adverse events with hyperkalemia (potassium $>5.5 \mathrm{mEq} / \mathrm{L}$ ), hypercalcemia (calcium $>10.5 \mathrm{mg} / \mathrm{dL}$ ), and hyperphosphatemia (phosphorus $>5.5 \mathrm{mg} / \mathrm{dL}$ ) among patients given dietary supplement did not significantly increase. At the study's completion, no subject had developed any adverse event or hospitalization or died.

\section{Discussion}

This research comprised a clinical study regarding ODF supplement among CAPD patients. The ODF supplement increased the energy, protein, carbohydrate, fat, fiber, calcium and magnesium intake with significant changes observed in body weight, serum prealbumin, and BUN in a CAPD population. Thus, ODF supplement tended to benefit the CAPD population. However, the finding comprised a shortterm clinical outcome.

Malnutrition and inadequate dialysis have a high risk of mortality, even after adjusting for well-known mortality risk factors. ${ }^{14,15}$ Dietary counseling and supplementation play an important role in patients with chronic dialysis, to improve nutrient intake, nutritional status, and quality of life in patients with CAPD. ${ }^{11,12}$ This preliminary study confirmed that hypoalbuminemic dialysis patients treated with dietary counseling and ODF supplement had higher nutrient intake, body weight, and serum prealbumin concentrations 
Table 4 Nutritional and laboratory parameters at baseline and end of I5-day follow-up

\begin{tabular}{|c|c|c|c|c|}
\hline Variables & Baseline & End & Mean change $(95 \% \mathrm{Cl})$ & $P$-value \\
\hline \multicolumn{5}{|c|}{ Nutrition and inflammatory parameters } \\
\hline Body weight (kg) & $53.7 \pm 9.5$ & $54.5 \pm 9.2$ & $0.7(0.1$ to 1.3$)$ & 0.017 \\
\hline Serum albumin $(g / d L)$ & $3.2 \pm 0.5$ & $3.2 \pm 0.5$ & $-0.1(-0.13$ to 0$)$ & 0.062 \\
\hline Prealbumin (mg/dL) & $33.8 \pm 11.1$ & $35.4 \pm 10.1$ & $1.6(0.4$ to 2.8$)$ & 0.008 \\
\hline Hemoglobin (g/dL) & $10.6 \pm 2.1$ & $10.5 \pm 2.0$ & $-0.2(-0.5$ to 0.1$)$ & 0.280 \\
\hline White blood cell count $\left(10^{6} / \mathrm{mL}\right)$ & $8.1 \pm 3.1$ & $8.2 \pm 2.4$ & $0.13(-0.5$ to 0.8$)$ & 0.658 \\
\hline Lymphocyte count (\%) & $21.5 \pm 6.8$ & $20.9 \pm 8.4$ & $-0.6(-2.5$ to 1.2$)$ & 0.487 \\
\hline FPG (mg/dL) & $120.9 \pm 52.5$ & $124.2 \pm 76.8$ & $3.3(-20.6$ to 27.1$)$ & 0.782 \\
\hline BUN (mg/dL) & $45.8 \pm 13.9$ & $49.9 \pm 15.9$ & $4.2(1.4$ to 6.9$)$ & 0.005 \\
\hline Serum creatinine (mg/dL) & $8.5 \pm 3.3$ & $8.4 \pm 3.3$ & $-0.1(-0.4$ to 0.3$)$ & 0.688 \\
\hline High-sensitivity CRP (mg/dL) & $5.2 \pm 9.8$ & $2.4 \pm 3.6$ & $-2.8(-6.4$ to 0.8$)$ & 0.124 \\
\hline \multicolumn{5}{|c|}{ Serum electrolytes and mineral parameters } \\
\hline Sodium $(\mathrm{mEq} / \mathrm{L})$ & $132.9 \pm 6.1$ & $134.8 \pm 5.3$ & $1.9(0.8$ to 3.0$)$ & 0.002 \\
\hline Sodium $<135 \mathrm{mEq} / \mathrm{L}$ & $18(54.5 \%)$ & $15(45.5 \%)$ & & 0.257 \\
\hline Potassium (mEq/L) & $3.9 \pm 0.7$ & $4.0 \pm 0.8$ & $0.07(-0.2$ to 0.3$)$ & 0.510 \\
\hline Potassium $<3.5 \mathrm{mEq} / \mathrm{L}$ & $26(78.8 \%)$ & $9(27.3 \%)$ & & 0.001 \\
\hline Potassium $>5.5 \mathrm{mEq} / \mathrm{L}$ & $0(0 \%)$ & I (3\%) & & 0.317 \\
\hline Chloride(mEq/L) & $95.6 \pm 5.6$ & $91.3 \pm 6.5$ & $-4.4(-5.9$ to -2.7$)$ & $<0.001$ \\
\hline Bicarbonate (mg/dL) & $28.4 \pm 2.4$ & $26.8 \pm 2.1$ & $-1.6(-2.4$ to -0.8$)$ & $<0.001$ \\
\hline Bicarbonate $<24 \mathrm{mEq} / \mathrm{L}$ & $2(6.1 \%)$ & $3(9.1 \%)$ & & 0.564 \\
\hline Calcium (mg/dL) & $8.6 \pm 0.6$ & $8.7 \pm 0.7$ & $0.2(0$ to 0.3$)$ & 0.046 \\
\hline Phosphorus (mg/dL) & $3.9 \pm 1.0$ & $3.9 \pm 1.2$ & -0.01 ( $(-0.3$ to 0.2$)$ & 0.952 \\
\hline \multicolumn{5}{|c|}{ Residual renal electrolytes and renal clearance } \\
\hline Urine sodium (mEq/day) & $61.9 \pm 55.5$ & $59.7 \pm 44.9$ & $-2.7(-15.1$ to 9.7$)$ & 0.663 \\
\hline Urea clearance $(\mathrm{mL} / \mathrm{min})$ & $3,579.2 \pm 2,917.1$ & $3,174.9 \pm 2,560.9$ & $-305.8(-840.4$ to 228.8$)$ & $0.25 I$ \\
\hline Creatinine clearance $(\mathrm{mL} / \mathrm{min})$ & $6,344.4 \pm 5,039.8$ & $5,899.3 \pm 4,419.9$ & $-276.8(-962.7$ to 409.0$)$ & 0.415 \\
\hline
\end{tabular}

Notes: Data presented as mean \pm SD and mean change $(95 \% \mathrm{Cl})$. $P$-value corresponds to paired $t$-test and Wilcoxon signed ranks test.

Abbreviations: BUN, blood urea nitrogen; CRP, C-reactive protein; FPG, fasting plasma glucose; SD, standard deviation; Cl, confidence interval.

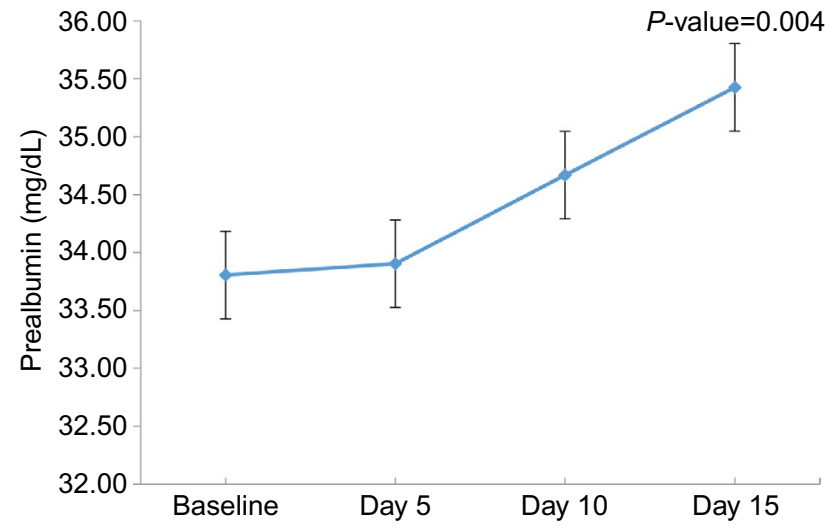

Figure I Mean changes of serum prealbumin after ODF supplement. Abbreviations: ODF, ONCE dialyze formula; ONCE, Otsuka Nutrition Pharmaceutical.

along with decreasing modified SGA scores. Similarly, oral nutritional supplement improved caloric intake and nutritional status among patients on maintenance hemodialysis and peritoneal dialysis. ${ }^{16,17}$ Further studies of the efficacy of ODF regimen with respect to improving clinical outcomes are required regarding severe malnourished dialysis patients.

Dialysis patients are recommended to have a daily protein intake of $>1.2 \mathrm{~g} / \mathrm{kg} /$ day and an energy intake of 30-35 kcal/ $\mathrm{kg} /$ day. ${ }^{18,19}$ Inadequate dietary intake is considered the most important cause of malnutrition among dialysis patients, and patients with CAPD have more inadequate dietary intakes than do hemodialysis patients. ${ }^{20}$ Despite the common use of oral nutritional supplements among patients with CAPD, little evidence has shown improvement of nutritional status especially serum albumin concentration and in achieving the recommended nutritional target. One study documented that serum albumin rose from $2.6 \pm 0.4$ to $3.1 \pm 0.7 \mathrm{~g} / \mathrm{dL}$ after 6 months of oral nutritional supplement. ${ }^{17}$ However, in this study and other related studies, ${ }^{21,22}$ no significant changes were observed in serum albumin concentration after intervention. The explanation for the negative finding was probably that at the end of follow-up, the subjects of this study continued to show significantly lower nutritional intake than recommended, and only a short-term nutritional supplement for 15 days was provided. A longer follow-up or a higher nutrition supplement may provide clearer evidence for improvement of serum albumin level. In addition, the use of serum albumin as a marker of malnutrition among dialysis patients is controversial because albumin levels are relatively insensitive to changes in nutrition. Albumin has a relatively large body pool and a half-life of 20 days. Serum albumin levels are affected by the patient's state of hydration, and 
almost all patients with CAPD had volume overload. Causes of hypoalbuminemia among the patients with CAPD of this study were clearly present including volume overload, aging, diabetes, and high transporters of peritoneal membrane.

However, in this study, for CAPD dialysis patients treated with ODF supplement, serum prealbumin concentrations significantly improved, but serum albumin did not change. The nutritional care consensus group recommended checking serum prealbumin levels in all patients admitted to the hospital with malnutrition or nutritional risk factors such as renal disease because the level of prealbumin is a sensitive method of assessing the nutrient intake and nutritional status among patients with chronic illness. ${ }^{23}$ In addition, the volume status does not affect the prealbumin levels, and prealbumin levels have been shown to correlate with patient outcomes and predict survival among patients undergoing hemodialysis and peritoneal dialysis. ${ }^{24,25}$

Malnutrition, inflammation, and atherosclerosis (MIA) syndrome is important, and it has been reported that malnutrition and inflammation were risk factors for cardiovascular disease in dialysis populations. ${ }^{26,27}$ As a marker of systemic inflammatory reaction, serum high-sensitive CRP is the one of the predictors for developing cardiovascular disease and protein and energy wasting related to appetite suppression. Few studies have reported about nutritional supplement concerning inflammatory parameters. Intensive dietary counseling and dietary ODF supplement have led to improvement in nutrient intake and have tended to decrease high-sensitivity CRP in a CAPD population. However, the improvement in dietary intake may also be one effect of dialysis per se, but the adequacy of dialysis during the study remained unchanged. Further prospective longitudinal studies are needed to clarify the exact interrelations between nutrient intake and proinflammatory cytokines among dialysis patients.

The study had a few limitations. First, the single center of pilot study design was an unrandomized trial, and the results showed that ODF administration increased the initially low serum prealbumin concentrations concomitant with BUN concentrations and body weight among patients with CAPD. Fewer patients were included among moderate-to-severe malnourished dialysis patients, which could have more benefits of treatment on nutritional outcomes and status. In addition, the study had a short follow-up duration. Thus, it would have been better to have a longer follow-up period to understand the efficacy and safety of the long-term effects of ODF on nutritional status and main clinical outcomes. However, conducting a randomized clinical trial involving adjusted nutritional intake on long-term dialysis outcomes is difficult, and the use of surrogate outcomes rather than definitive outcomes may be an alternative option.

In conclusion, this prospective study indicated that consuming special renal nutritional formula produces more energy, protein, nutrients, fiber, and appropriate electrolyte intake among patients with CAPD. This oral supplementation was associated with a trend toward improved modified SGA scores. Oral-specific ODF treatment may be an effective method of improving the nutritional status among peritoneal dialysis patients. Further large-scale studies using longer periods will be needed to clarify related issues.

\section{Acknowledgment}

This research was supported in part by a grant from Phramongkutklao Hospital and College of Medicine, Bangkok, Thailand.

\section{Disclosure}

The authors report no conflicts of interest in this work.

\section{References}

1. Adequacy of dialysis and nutrition in continuous peritoneal dialysis: association with clinical outcomes. Canada-USA (CANUSA) Peritoneal Dialysis Study Group. J Am Soc Nephrol. 1996;7(2):198-207.

2. Kang DH, Kang EW, Choi SR, Yoon SY, Han DS. Nutritional problems of Asian peritoneal dialysis patients. Perit Dial Int. 2003;23 Suppl 2: S58-S64.

3. Young GA, Kopple JD, Lindholm B, et al. Nutritional assessment of continuous ambulatory peritoneal dialysis patients: an international study. Am J Kidney Dis. 1991;17(4):462-471.

4. Cianciaruso B, Brunori G, Kopple JD, et al. Cross-sectional comparison of malnutrition in continuous ambulatory peritoneal dialysis and hemodialysis patients. Am J Kidney Dis. 1995;26(3):475-486.

5. Rocco MV, Paranandi L, Burrowes JD, et al. Nutritional status in the HEMO Study cohort at baseline. Hemodialysis. Am J Kidney Dis. 2002;39(2):245-256.

6. Blumenkrantz MJ, Kopple JD, Moran JK, Coburn JW. Metabolic balance studies and dietary protein requirements in patients undergoing continuous ambulatory peritoneal dialysis. Kidney Int. 1982;21(6):849-861.

7. Dukkipati R, Kopple JD. Causes and prevention of protein-energy wasting in chronic kidney failure. Seminars Nephrol. 2009;29(1):39-49.

8. Supasyndh O, Satirapoj B, Seenamngoen S, Yongsiri S, Choovichian P, Vanichakarn S. Nutritional status of twice and thrice-weekly hemodialysis patients with weekly Kt/V > 3.6. J Med Assoc Thai. 2009;92(5):624-631.

9. Wang AY, Sanderson J, Sea MM, et al. Important factors other than dialysis adequacy associated with inadequate dietary protein and energy intakes in patients receiving maintenance peritoneal dialysis. Am J Clin Nutr. 2003;77(4):834-841.

10. Kovesdy CP, Kopple JD, Kalantar-Zadeh K. Management of proteinenergy wasting in non-dialysis-dependent chronic kidney disease: reconciling low protein intake with nutritional therapy. Am J Clin Nutr. 2013;97(6):1163-1177.

11. Boudville N, Rangan A, Moody H. Oral nutritional supplementation increases caloric and protein intake in peritoneal dialysis patients. $\mathrm{Am}$ J Kidney Dis. 2003;41(3):658-663.

12. Shimomura A, Tahara $D$, Azekura $H$. Nutritional improvement in elderly CAPD patients with additional high protein foods. Adv Perit Dial. 1993;9:80-86. 
13. Cano N, Fiaccadori E, Tesinsky P, et al. ESPEN guidelines on enteral nutrition: adult renal failure. Clin Nutr. 2006;25(2):295-310.

14. Pifer TB, McCullough KP, Port FK, et al. Mortality risk in hemodialysis patients and changes in nutritional indicators: DOPPS. Kidney Int. 2002; 62(6):2238-2245.

15. Leinig CE, Moraes T, Ribeiro S, et al. Predictive value of malnutrition markers for mortality in peritoneal dialysis patients. J Ren Nutr. 2011; 21(2):176-183.

16. Caglar K, Fedje L, Dimmitt R, Hakim RM, Shyr Y, Ikizler TA. Therapeutic effects of oral nutritional supplementation during hemodialysis. Kidney Int. 2002;62(3):1054-1059.

17. Gonzalez-Espinoza L, Gutierrez-Chavez J, del Campo FM, et al. Randomized, open label, controlled clinical trial of oral administration of an egg albumin-based protein supplement to patients on continuous ambulatory peritoneal dialysis. Perit Dial Int. 2005;25(2):173-180.

18. Cano NJ, Aparicio M, Brunori G, et al. ESPEN guidelines on parenteral nutrition: adult renal failure. Clin Nutr. 2009;28(4):401-414.

19. Kopple JD, Blumenkrantz MJ. Nutritional requirements for patients undergoing continuous ambulatory peritoneal dialysis. Kidney Int Suppl. 1983;16:S295-S302.

20. Kopple JD. Pathophysiology of protein-energy wasting in chronic renal failure. J Nutr. 1999;129(1S Suppl):247S-251S.
21. Eustace JA, Coresh J, Kutchey C, et al. Randomized double-blind trial of oral essential amino acids for dialysis-associated hypoalbuminemia. Kidney Int. 2000;57(6):2527-2538.

22. Heaf JG, Honore K, Valeur D, Randlov A. The effect of oral protein supplements on the nutritional status of malnourished CAPD patients. Perit Dial Int. 1999;19(1):78-81.

23. Measurement of visceral protein status in assessing protein and energy malnutrition: standard of care. Prealbumin in Nutritional Care Consensus Group. Nutrition. 1995;11(2):169-171.

24. Mears E. Outcomes of continuous process improvement of a nutritional care program incorporating serum prealbumin measurements. Nutrition. 1996;12(7-8):479-484.

25. Sreedhara R, Avram MM, Blanco M, Batish R, Avram MM, Mittman N. Prealbumin is the best nutritional predictor of survival in hemodialysis and peritoneal dialysis. Am J Kidney Dis. 1996;28(6):937-942.

26. Stenvinkel P. Malnutrition and chronic inflammation as risk factors for cardiovascular disease in chronic renal failure. Blood Purif 2001;19(2):143-151.

27. Henriquez D, Dikow R, Ritz E. Cardiovascular disease in chronic renal failure. Risk factors and prevention. Nefrologia. 2004;24 Suppl 4: 34-39.
The International Journal of Nephrology and Renovascular Disease is an international, peer-reviewed open access journal focusing on the pathophysiology of the kidney and vascular supply. Epidemiology, screening, diagnosis, and treatment interventions are covered as well as basic science, biochemical and immunological studies. The manuscript management system is completely online and includes a very quick and fair peer-review system, which is all easy to use. Visit http://www. dovepress.com/testimonials.php to read real quotes from published authors. 